\title{
Alterations of the enzyme output in ethionine pancreatitis
}

\author{
KURT MÚLLER-WIELAND ${ }^{1}$ \\ From Manchester Royal Infirmary
}

EDITORIAL SYNOPSIS In this study of pancreatitis induced by ethionine the outputs of amylase, trypsin, and lipase were diminished simultaneously.

The pancreatic enzymes, amylase, trypsinogen, and lipase, are excreted concurrently in healthy man (Lagerlöf, 1942; Burton, Evans, Harper, Howat, Oleesky, Scott, and Varley, 1960). In some cases of chronic pancreatitis a loss of activity of one enzyme has been reported while the concentration of the other two has not been affected (Lagerlöf, 1939; Diamond and Siegel, 1941). In the present study ethionine was given to produce pancreatitis in rats. Using this model experiments were designed to investigate the pattern of the output of enzymes in the ethionine-poisoned state.

\section{METHODS}

Male rats only were used, because an excessive fatty degeneration of the liver occurs in female rats in the early stage of ethionine toxicity (Farber, Koch-Weser, and Popper, 1951, Becker; 1957).

Sixty-one male albino rats ranging in weight from 200 to $300 \mathrm{~g}$. were injected subcutaneously with $4 \mathrm{mg}$. atropine. Fifteen minutes later light ether anaesthesia was induced, the abdomen opened and anaesthesia continued by the injection of $0.75 \mathrm{ml}$. of a $5 \%$ urethane solution into the caecum. After tying off the pylorus the main bile duct was occluded by a ligature tied close to the hilum of the liver, and cannulated by a polyethylene catheter $(0.98 \mathrm{~mm}$. o.d.) introduced close to the duodenal wall. Samples of pancreatic juice from the numerous pancreatic ducts entering the main bile duct were drained by continuous suction using a negative pressure of 1 to $2 \mathrm{~cm}$. of water.

Exocrine pancreatic secretion was stimulated by secretin and pancreozymin (Boots). For the first 60 minutes 2 units of secretin (Crick, Harper, and Raper, 1949) were infused into the jugular vein every five minutes; for the subsequent 30 minutes 2 units of both secretin and pancreozymin were given every five minutes.

Pancreatic juice was fractionated into glass tubes surrounded by ice, the volume measured, and the specimens kept in a deep freeze chamber until amylase activity was

'Address: I. Medizinische Klinik, Universitat Hamburg, 2 Hamburg 20. Martinistr. 52/54. estimated by the method of Norby (Lagerlöf, 1942), lipase activity by the method of Marchis-Mouren, Sarda, and Desnuelle (1959), and the concentration of trypsin activated by enterokinase (Kunitz, 1939) was measured by the method of Gowenlock (1953), in which the phenolic substances liberated from denatured human serum protein by the enzyme are determined colorimetrically. On completing the test of pancreatic function the rats were deeply anaesthetized with pentobarbital and killed by heart section. The pancreas was removed, fixed in $10 \%$ formalin at $37^{\circ} \mathrm{C}$., embedded in paraffin, and examined histologically. Sections were stained with haematoxylin and eosin.

Pancreatitis was induced by ethionine. Four animals (group 10) were given ethionine two hours before the test by continuous infusion. Ethionine was also given to other batches of rats intraperitoneally. In the first series (groups 1 to 5) the dose was increased from 0.33 to 1.66 $\mathrm{mg}$./g. of body weight. Each injection contained 0.33 mg./g. body weight and in 24 hours not more than 1.00 $\mathrm{mg}$./g. body weight was given. Pancreatic function was estimated 12 hours after the last injection. The second series was designed to study recovery from ethionine pancreatitis. In groups $3,6,7$, and 8 the animals were each given the same dose of $1.0 \mathrm{mg}$./g. body weight of ethionine and pancreatic function was studied at intervals of $24,48,72$, and 120 hours, after the initial injection of ethionine.

In order to investigate the early changes in ethionine pancreatitis, in group $100.33 \mathrm{mg}$./g. body weight of ethionine was administered intravenously and the test performed immediately after the infusion. In group 11 the test of pancreatic function was done eight hours after a single.injection of $0.33 \mathrm{mg} . / \mathrm{g}$. body weight of ethionine, given intraperitoneally.

In gre $9,0.33 \mathrm{mg}$. $/ \mathrm{g}$. body weight of ethionine was administered daily for three days and pancreatic function estimated 24 hours after the last injection.

\section{RESULTS}

The toxic effect of ethionine is revealed in the acinar cells. This intracellular stage of poisoning is followed by a reaction in the surrounding connective 
tissue with the appearance of fibroblasts and histiocytes which increase the separation of the lobules and acini. Finally the exocrine parenchyma entirely degenerates (Goldberg and Chaikoff, 1951; Becker, 1957). In our experiments it was impossible to withdraw pancreatic juice quantitatively in an advanced stage of ethionine pancreatitis. After stimulation by secretin and pancreozymin the tissues were swollen by considerable oedema. Presumably this resulted from damage to the pancreatic ductules. Therefore this investigation concerned the earlier phases of ethionine intoxication when quantitative recovery of the secretion was still possible.

The pylorus was ligatured to exclude stomach contents from the duodenum, thereby preventing endogenous pancreatic stimulation. Atropine was also administered to eliminate vagal activity. Under these conditions, fasting pancreatic secretion is completely eliminated in rats and exocrine pancreatic secretion is wholly dependent on the injected secretin and pancreozymin. Preliminary trials showed that secretin in the dosage used accounted for the 'washing out' of most of the stored enzyme content of the pancreas in one hour.

CONTROLS In 13 control animals the standard errors of the mean for volume and output of amylase, trypsin, and lipase during the secretin period were $6.75 .7 .53,9.45$, and $6.42 \%$ and for the pancreozymin phase $9 \cdot 63,15 \cdot 7,12 \cdot 9$, and $8 \cdot 25 \%$.

Histological investigations of the pancreas in the control group showed areas in which the acinar cells had become vacuolated, the vacuoles being few in number though of considerable size.

INCREASING DOSES OF ETHIONINE (EXPERIMENTAL GROUPS 1 TO 5) In rats given from 0.35 to 1.00 $\mathrm{mg}$./g. body weight of ethionine the volumes of the pancreatic juice remained within the normal range with a variation of 1 standard deviation from the mean in most animals (groups 1-3). With doses of 1.33 and $1.66 \mathrm{mg} . / \mathrm{g}$. body weight (groups 4 and 5) the volumes decreased. The reduction of enzyme output which occurred with increasing poisoning affected all enzymes equally. The variation was greater in the secretin phase than in the pancreozymin period. With lower doses of ethionine (groups 2 and 3 ) the output of trypsin and lipase exceeded the upper limit of controls in some animals (Figs. 1a and $1 \mathrm{~b}$, Table I).

Histologically the acinar cells showed a generalized loss of basal basophilia and reduced granularity of the apical cytoplasm. The basement membrane showed fragmentation. With increasing doses of ethionine the cells either stained homogeneously or contained small cytoplasmic vacuoles close to the basement membrane. Simultaneously, increasing numbers of acinar cells were seen to be detached from the basement membrane and had become necrotic.

INVESTIGATION OF THE EXOCRINE FUNCTION OF THE PANCREAS ONE, TWO, THREE, AND FIVE DAYS AFTER ETHIONINE POISONING (EXPERIMENTAL GROUPS 3, 6-8) The rats were given $1 \mathrm{mg} . / \mathrm{g}$. body weight as three

TABLE I

VOLUME AND OUTPUT OF AMYLASE, TRYPSIN, AND LIPASE AFTER SECRETIN AND PANCREOZYMIN AND MEANS AND SIGNIFICANCE OF DIFFERENCE BETWEEN MEANS OF NORMAL AND ABNORMAL GROUPS OF RATS WITH ETHIONINE PANCREATITIS

\begin{tabular}{|c|c|c|c|c|c|c|c|c|c|c|c|c|c|c|c|c|c|}
\hline \multirow[t]{3}{*}{ Group } & \multirow[t]{3}{*}{ No. } & \multicolumn{8}{|c|}{ Volume $\left(\mathrm{ml} .10^{3}\right)$} & \multicolumn{8}{|c|}{ Amylase Output (Norby units) } \\
\hline & & \multicolumn{4}{|c|}{ Secretin Period } & \multicolumn{4}{|c|}{ Pancreozymin Period } & \multicolumn{4}{|c|}{ Secretin Period } & \multicolumn{4}{|c|}{ Pancreozymin Period } \\
\hline & & Mean & S.D. & $t$ & $p$ & Mean & S.D. & $t$ & $\boldsymbol{p}$ & Mean & S.D. & $t$ & $\boldsymbol{p}$ & Mean & S.D. & $t$ & $\boldsymbol{p}$ \\
\hline Controls & 13 & 547 & 128 & & & 242 & $77 \cdot 5$ & & & 585 & 108 & & & 105 & 37 & & \\
\hline \multicolumn{18}{|c|}{ Increasing doses of ethionine } \\
\hline 1 & 5 & 490 & 50 & & & 205 & 26 & & & 510 & 22 & & & 107 & 34 & & \\
\hline 2 & 7 & 464 & 26 & & & 180 & 40 & $2 \cdot 220$ & $0.05-0.02$ & 570 & 108 & & & 110 & 66 & & \\
\hline 3 & 4 & 488 & 22 & & & 198 & 37 & & & 362 & 357 & & & 61 & 32 & & \\
\hline 4 & 4 & 413 & 110 & & & 146 & 54 & $2 \cdot 68$ & $0.05-0.02$ & 195 & 47 & $7 \cdot 78$ & $0.001-0.0001$ & 31 & 15 & $4 \cdot 04$ & $0.01-0.001$ \\
\hline 5 & 4 & 424 & 72 & $2 \cdot 37$ & $0.05-0.02$ & 169 & 24 & $\mathbf{2 \cdot 7 8}$ & $0.05-0.02$ & 260 & 68 & 5.82 & $0.001-0.0001$ & 39 & 21 & $\mathbf{3 \cdot 3 3}$ & $0.01-0.001$ \\
\hline \multicolumn{18}{|c|}{ Test $1,2,3$, and 5 days after ethionine poisoning } \\
\hline 3 & 4 & 488 & 22 & & & 198 & 37 & & & 362 & 357 & & & 61 & 32 & & \\
\hline 6 & 4 & 389 & 124 & & & 159 & 47 & $2 \cdot 51$ & $0.05-0.02$ & 246 & 42 & $4 \cdot 88$ & $0.001-0.0001$ & 51 & 12 & 3.08 & $0.02-0.01$ \\
\hline 7 & 4 & 418 & 86 & & & 190 & 38 & & & 343 & 109 & 3.45 & $0.01-0.001$ & 152 & 65 & & \\
\hline 8 & 4 & 600 & 71 & & & 253 & 75 & & & 493 & 55 & & & 132 & 39 & & \\
\hline \multicolumn{18}{|c|}{ Continued administration of ethionine over 3 days } \\
\hline 9 & 4 & 359 & 131 & $2 \cdot 51$ & $0.05-0.02$ & 166 & 63 & & & 336 & 84 & 4.07 & $0.01-0.001$ & 138 & 37 & & \\
\hline \multicolumn{18}{|c|}{ Test immediately after intravenous infusion and 8 hours after intraperitoneal injection } \\
\hline $\begin{array}{l}10 \\
11\end{array}$ & $\begin{array}{l}4 \\
4\end{array}$ & $\begin{array}{l}391 \\
642\end{array}$ & $\begin{array}{l}68 \\
77\end{array}$ & 3.09 & $0.02-0.01$ & $\begin{array}{l}125 \\
249\end{array}$ & $\begin{array}{l}42 \\
77\end{array}$ & $3 \cdot 75$ & $0.0-0.001$ & $\begin{array}{l}508 \\
848\end{array}$ & $\begin{array}{r}77 \\
242\end{array}$ & & & $\begin{array}{r}54 \\
137\end{array}$ & $\begin{array}{l}20 \\
50\end{array}$ & $2 \cdot 64$ & $0.05-0.02$ \\
\hline
\end{tabular}


single doses (each $0.33 \mathrm{mg} . / \mathrm{g}$. body weight) and exocrine pancreatic function was tested after 24, 48, 72 , and 120 hours. Following the injection of ethionine there was a fall in enzyme output maximal on the second day; thereafter it was gradually restored to normal by the fifth day (Figs. $2 a$ and $2 b$, Table I).

Histologically the normal structure of the acinar cells, particularly the basophilia, was restored after five days.

CONTINUAL ADMINISTRATION OF ETHIONINE OVER THREE DAYS (EXPERIMENTAL GROUP 9) In spite of a reduction of the volume and output of amylase and lipase excretion of trypsin was not affected to the same extent (Table 1).

Loss of cellular basophilia, fragmentation of the basement membrane, and persistence of some symogen granules were histological features.

ESTIMATION OF PANCREATIC SECRETION IMMEDIATELY AFTER THE INTRAVENOUS INFUSION OF ETHIONINE (GROUP 10) AND EIGHT HOURS AFTER INTRAPERITONEAL ADMINISTRATION OF SAME DOSE OF ETHIONINE (GROUP 11) In group 10, the volume and the output of the enzymes were reduced while in group 11 the exocrine function was not impaired; in fact some samples of enzyme showed levels above the normal range (Table I).

Loss of basophilia, retention of enzyme granules, and fragmentation of the basement membrane were more often observed after intravenous infusion of ethionine than after intraperitoneal injection.
DISCUSSION

The ethyl-homologue of methionine, ethionine, causes a metabolic disturbance particularly in cells with a high rate of protein synthesis. Acinar cells are more affected by ethionine than ductule isthmus cells, because the initial effect of the poisoning is to depress the enzyme output while the volume remains normal. Larger doses of ethionine, however, not only damage both types of cells but also delay recovery of cell function.

In spite of strong stimulation of the exocrine pancreatic function the acinar cells in the neighbourhood of the islets retain enzyme granules. Sergeyeva (1938) called this histological finding 'the halo phenomenon'. Preliminary trials showed that atropine used in a dose of $4 \mathrm{mg}$. prevents this halo phenomenon. Indeed after stimulating the exocrine pancreas by secretin and pancreozymin almost all acinar cells were emptied of zymogen granules.

Secretin produces a large volume of pancreatic juice of constant alkalinity which washes out preformed enzyme from the pancreatic ducts. Pancreozymin increases the enzyme output by the pancreas without affecting the volume of the juice (Harper and Mackay, 1948). In our experiment, despite strong stimulation by secretin and pancreozymin, some acinar cells retained zymogen granules adjacent to the empty lumen, as well as around the islets. The presence of vacuoles in the cells might indicate that they are responsive to hormone stimula-

TABLE I continued

VOLUME AND OUTPUT OF AMYLASE, TRYPSIN, AND LIPASE AFTER SECRETIN AND PANCREOZYMIN AND MEANS AND SIGNIFICANCE OF DIFFERENCE BETWEEN MEANS OF NORMAL AND ABNORMAL GROUPS OF RATS WITH ETHIONINE PANCREATITIS Trypsin Output (Gowenlock units) Lipase Output (Desnuelle units)

\begin{tabular}{|c|c|c|c|c|c|c|c|c|c|c|c|c|c|c|c|}
\hline \multicolumn{4}{|c|}{ Secretin Period } & \multicolumn{4}{|c|}{ Pancreozymin Period } & \multicolumn{4}{|c|}{ Secretin Period } & \multicolumn{4}{|c|}{ Pancreozymin Period } \\
\hline Mean & S.D. & $t$ & $p$ & Mean & $S . D$. & $t$ & $p$ & Mean & S.D. & $t$ & $p$ & Mean & S.D. & $t$ & $p$ \\
\hline 687 & 184 & & & 232 & 68 & & & 243 & 42 & & & 100 & $16 \cdot 5$ & & \\
\hline $\begin{array}{l}904 \\
813 \\
394 \\
453 \\
438\end{array}$ & $\begin{array}{r}192 \\
214 \\
116 \\
97 \\
45\end{array}$ & $\begin{array}{l}3.03 \\
\\
3 \cdot 36 \\
2 \cdot 97 \\
3 \cdot 62\end{array}$ & $\begin{array}{l}0.01-0.001 \\
0.01-0.001 \\
0.05-0.02 \\
0.01-0.001\end{array}$ & $\begin{array}{r}284 \\
257 \\
138 \\
108 \\
95\end{array}$ & $\begin{array}{l}62 \\
58 \\
55 \\
16 \\
11\end{array}$ & $\begin{array}{l}2 \cdot 28 \\
3.95 \\
4 \cdot 42\end{array}$ & $\begin{array}{l}0.05-0.02 \\
0.01-0.001 \\
0.01-0.001\end{array}$ & $\begin{array}{l}295 \\
276 \\
147 \\
135 \\
131\end{array}$ & $\begin{array}{l}41 \\
49 \\
55 \\
50 \\
28\end{array}$ & $\begin{array}{l}3 \cdot 04 \\
3 \cdot 67 \\
4 \cdot 78\end{array}$ & $\begin{array}{l}0.02-0.01 \\
0.01-0.001 \\
0.001-0.0001\end{array}$ & $\begin{array}{l}84 \\
79 \\
44 \\
30 \\
30\end{array}$ & $\begin{array}{r}27 \cdot 2 \\
16 \cdot 8 \\
17 \cdot 7 \\
9 \cdot 2 \\
1 \cdot 0\end{array}$ & $\begin{array}{l}4 \cdot 63 \\
7 \cdot 45 \\
8 \cdot 48\end{array}$ & $\begin{array}{l}0.01-0.001 \\
0.001-0.0001 \\
0.001-0.0001\end{array}$ \\
\hline $\begin{array}{l}394 \\
248 \\
296 \\
778\end{array}$ & $\begin{array}{r}116 \\
50 \\
57 \\
130\end{array}$ & $\begin{array}{l}3 \cdot 36 \\
6 \cdot 30 \\
5 \cdot 52\end{array}$ & $\begin{array}{l}0.01-0.001 \\
0.001-0.0001 \\
0.001-0.0001\end{array}$ & $\begin{array}{l}138 \\
105 \\
123 \\
254\end{array}$ & $\begin{array}{l}55 \\
33 \\
39 \\
62\end{array}$ & $\begin{array}{l}2 \cdot 28 \\
3 \cdot 52 \\
3 \cdot 02\end{array}$ & $\begin{array}{l}0.05-0.02 \\
0.01-0.001 \\
0.02-0.01\end{array}$ & $\begin{array}{l}147 \\
114 \\
219 \\
249\end{array}$ & $\begin{array}{l}55 \\
32 \\
35 \\
57\end{array}$ & $\begin{array}{l}3 \cdot 04 \\
5 \cdot 76\end{array}$ & $\begin{array}{l}0.02-0.01 \\
0.001-0.0001\end{array}$ & $\begin{array}{l}44 \\
35 \\
69 \\
83\end{array}$ & $\begin{array}{r}17 \cdot 7 \\
9 \cdot 1 \\
18 \cdot 2 \\
17 \cdot 6\end{array}$ & $\begin{array}{l}4 \cdot 63 \\
6 \cdot 82 \\
2 \cdot 52\end{array}$ & $\begin{array}{l}0.01-0.001 \\
0.001-0.0001 \\
0.05-0.02\end{array}$ \\
\hline 637 & 202 & & & 215 & 22 & & & 161 & 49 & $2 \cdot 79$ & $0.05-0.02$ & 22 & 4.9 & 9.07 & $0.001-0.0001$ \\
\hline $\begin{array}{l}534 \\
935\end{array}$ & $\begin{array}{l}194 \\
261\end{array}$ & & & $\begin{array}{l}171 \\
238\end{array}$ & $\begin{array}{l}35 \\
89\end{array}$ & & & $\begin{array}{l}248 \\
232\end{array}$ & $\begin{array}{l}24 \\
20\end{array}$ & & & $\begin{array}{l}47 \\
30\end{array}$ & $\begin{array}{r}17.0 \\
1.8\end{array}$ & $\begin{array}{l}4.45 \\
5.78\end{array}$ & $\begin{array}{l}0.01-0.001 \\
0.01-0.001\end{array}$ \\
\hline
\end{tabular}



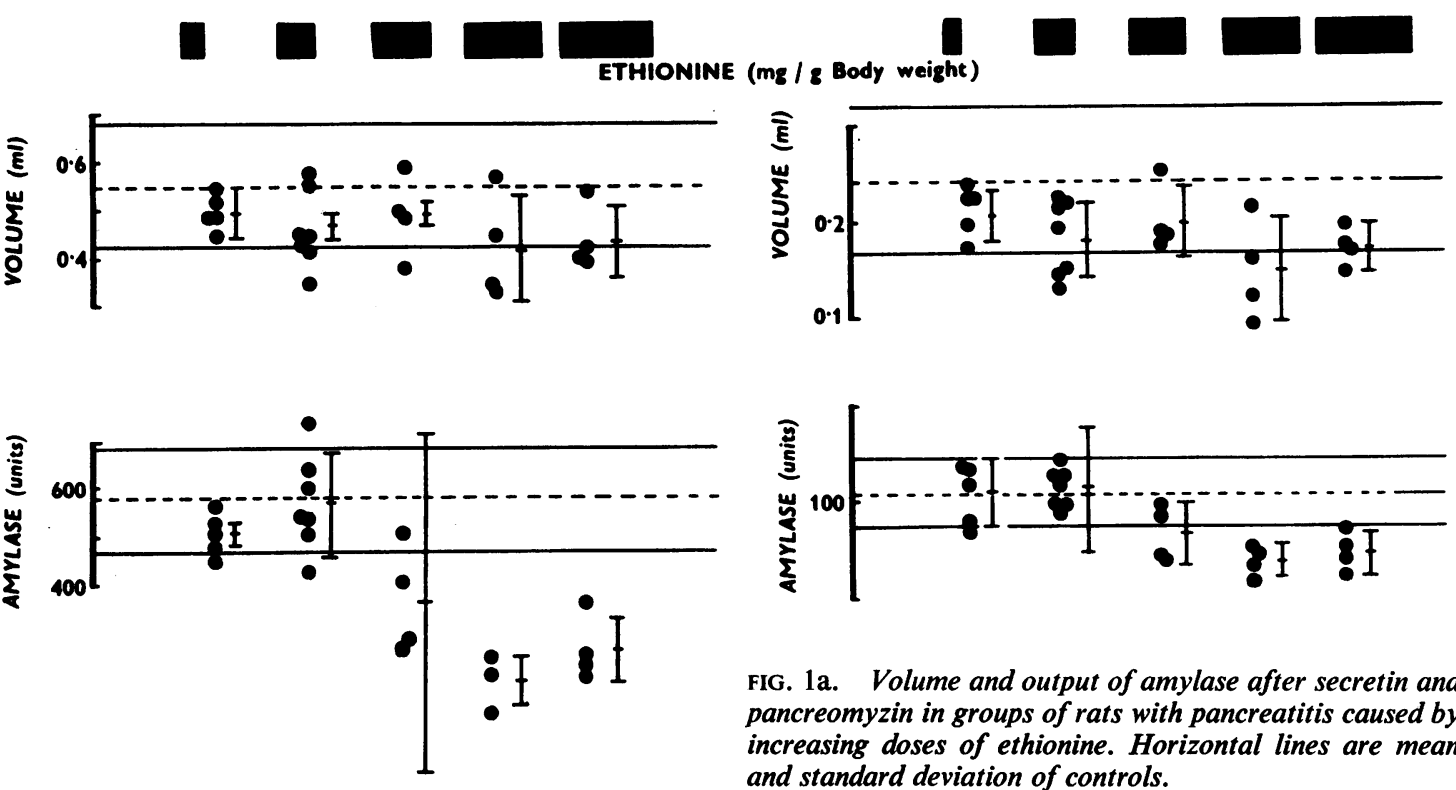

FIG. 1a. Volume and output of amylase after secretin and pancreomyzin in groups of rats with pancreatitis caused by increasing doses of ethionine. Horizontal lines are mean and standard deviation of controls.

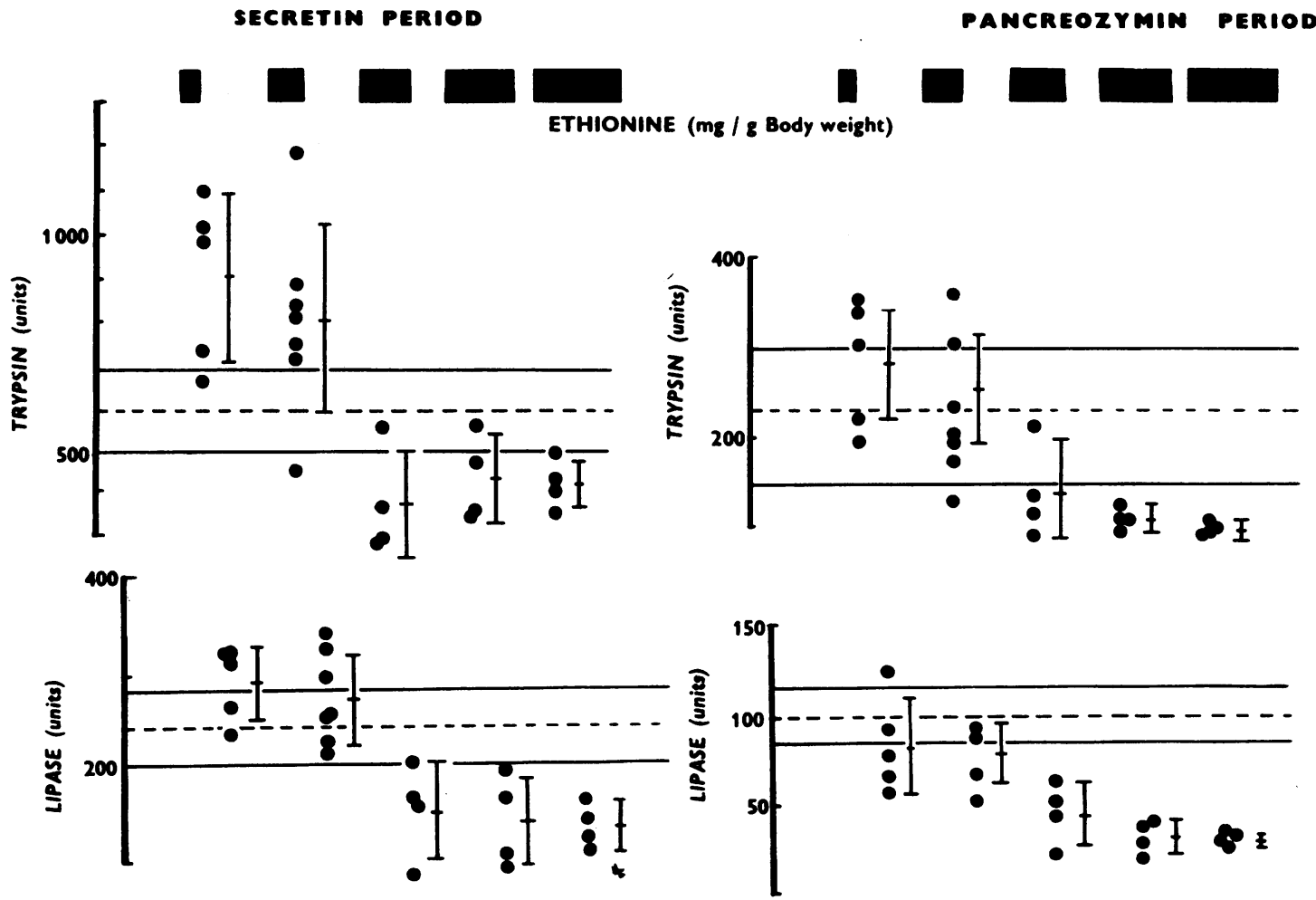

FIG. 1b. Output of trysin and lipase after secretin und pancreozymin of groups of rats with pancreatitis caused by increasing doses of ethionine. 

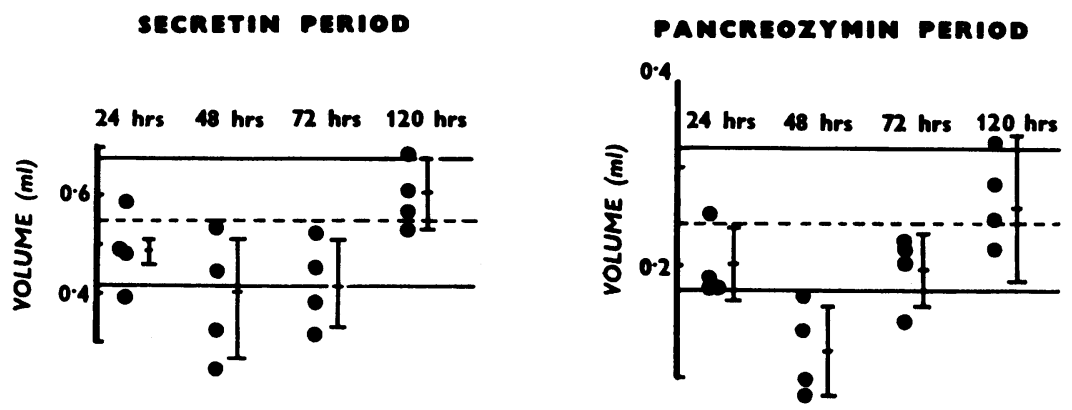

FIG. 2a. Volume and output of amylase after secretin and pancreozymin in groups of rats with pancreatitis induced by ethionine in the recovery period.

Horizontal lines are mean and standard deviation of controls.
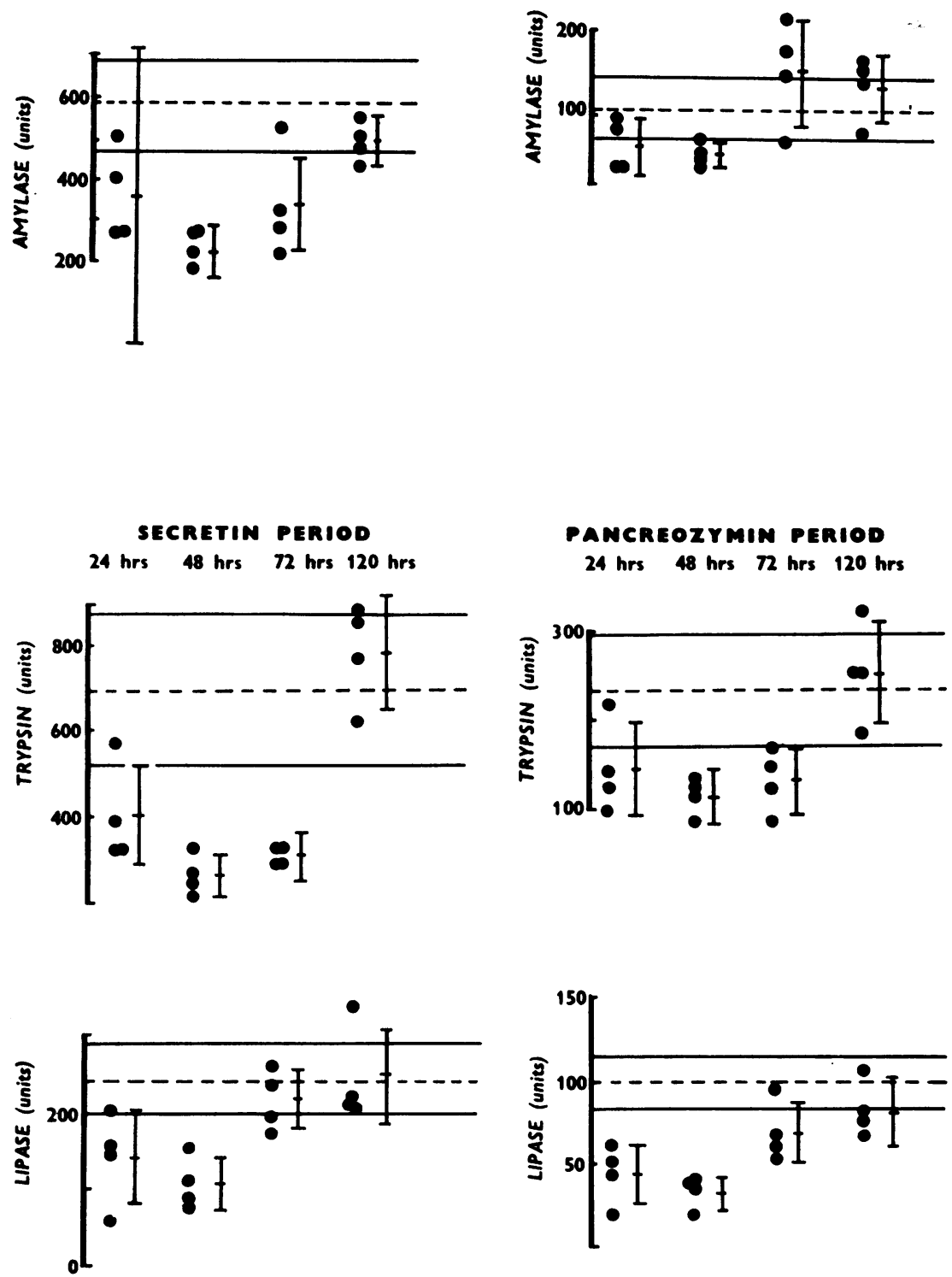

FIG. 2b. Output of trypsin and lipase after secretin and pancreozymin in groups of rats with ethionine pancreatitis in the recovery period. 
tion but are not reacting normally in the ethioninepoisoned state.

de Almeida and Grossman (1952) found that a diminished volume paralleled reduced bicarbonate, amylase, trypsin, and lipase excretion after ethionine given to dogs when pancreatic function was stimulated by secretin and urecholine. Véghelyi and Kemény (1962) showed that when albino rats were fed a methionine-free diet and then given secretin and pancreozymin there was a reduced concentration of ribonuclease and trypsin followed by a loss of lipase and chymotrypsin; amylase production, however, remained within normal limits.

In the present investigation ethionine intoxication reduced the secretion of amylase, trypsin, and lipase equally, the parallelism being particularly noticeable in the post-pancreozymin period. Thus 'enzyme dissociation' was not shown. However, there is some evidence that in the early stages of ethionine poisoning enzyme output may even exceed normal levels, and, by the methods used, diminished lipase output could be demonstrated earlier than the reduction of the other enzymes.

Goldberg and Chaikoff (1951) and Becker (1957) provide an accurate description of the histological appearances of ethionine-induced pancreatitis. The results of the present investigation agree with their findings in that at the beginning of ethionine poisoning, there was loss of the basophilia of the basal zone of the acinar cells. This appeared as early as two hours after the intravenous administration of ethionine. As this was essentially an acute experiment it was not possible to study the recovery process under these conditions. However, after the intraperitoneal administration of $1 \mathrm{mg}$./g. body weight ethionine basophilia was restored after five days. With increasing ethionine intoxication the endoplasmic reticulum disappeared and small vacuoles appeared adjacent to the basement membrane; some acinar cells became detached and subsequently degenerated. The extra-acinar tissue showed early oedema. These morphological changes were not sufficiently clear-cut to allow a precise correlation with exocrine function to be established.

Investigation by electron microscope of ethionineinduced pancreatitis revealed that this poison caused simultaneous alterations in the ribonucleic acid granules, endoplasmic reticulum of the cytoplasm, cytomembrane and basement membrane (Seifert and Gieseking, 1961). Our experiments showed that both the production of the enzymes and their discharge from the acinar cells were affected.

The aetiology of chronic pancreatitis in man is still obscure. Presumably the metabolism of the acinar cells is altered in a manner similar to that shown by investigations of ethionine pancreatitis in rats. Vary- ing reduction in the levels of different enzymes (socalled enzyme dissociation) reported by some workers may well have resulted from either insufficient stimulation of exocrine secretion or from a lack of accuracy inherent in the methods used to assess enzyme activity.

\section{SUMMARY}

Pancreatitis was induced by ethionine in male albino rats. Exocrine pancreatic function was estimated after stimulating the pancreas with secretin and pancreozymin in groups treated with increasing doses of poison, both during the phase of intoxication and in the recovery period. Volume, amylase, trypsin, and lipase activity were measured, and the pancreatic tissue was examined histologically. Ethionine intoxication causes a parallel diminution of the output of amylase, trypsin, and lipase in rats.

I acknowledge the help of Dr. Henry T. Howat, Manchester Royal Infirmary, of Professor A. C. P. Campbell, of the Department of Pathology, and of Professor Walter Schlapp, of the Department of Physiology, University of Manchester. I am grateful to Dr. G. Williams, Dr. A. H. Gowenlock, and Dr. C. Crompton. I am indebted to the British Council who arranged for my period of study in Great Britain.

\section{REFERENCES}

de Almeida, A. L., and Grossman, M. I. (1952). Experimental production of pancreatitis with ethionine. Gastroenterology, 20 , 554-577.

Becker, V. (1957). Sekretionsstudien am Pankreas. Thieme, Stuttgart.

Burton, P., Evans, D. G., Harper, A. A., Howat, H. T., Oleesky, S. Scott, J. E., and Varley, H. (1960). A test of pancreatic function in man based on the analysis of duodenal contents after administration of secretin and pancreozymin. Gut, 1, 111-124.

Crick, J., Harper, A. A., and Raper, H. S. (1949). On the preparation of secretin and pancreozymin. J. Physiol. (Lond.), 110, 367-376.

Diamond, J. S., and Siegel, S. A. (1941). The clinical application of secretin in the study of pancreatic function. N.Y. St. J. Med. 41, 869-875.

Farber, E., Koch-Weser, D., and Popper, H. (1961). The influence of sex and of testosterone upon fatty liver due to ethionine. Endocrinology, 48, 2J5-212.

Goldberg, R. C., and Chaikoff, I. L. (1951). Selective pancreatic acinar destruction by di-ethionine. Arch. Path., 52, 230-238.

Gowenlock, A. H. (1953). The estimation of tryptic activity in duodenal contents. Biochem. J., 53, 274-277.

Harper, A. A., and Mackay, I. F. S. (1948). The effects of pancreozymin and of vagal nerve stimulation upon the histological appearance of the pancreas. J. Physiol. (Lond.), 107, 89-96.

Kunitz, M. (1939). Purification and concentration of enterokinase. J. gen. Physiol., 22, 447-450.

Lagerlöf, H. (1939). The secretin test of pancreatic function. Quart. J. Med., 8, 115.

- (1942). Pancreatic function and pancreatic disease studied by means of secretin. Acta med. scand., suppl., 128.

Marchis-Mouren, G., Sarda, L., and Desnuelle, P. (1959). Purification of hog pancreatic lipase. Arch. Biochem., 83, 309-319.

Seifert, G., and Gieseking, R. (1961). Elektronenmikroskopische Befunde am Rattenpankreas nach experimenteller Athioninschädigung. Beitr. path. Anat., 124, 81-107.

Sergeyeva, M. A. (1938). Microscopic changes in the pancreatic gland of the cat produced by sympathic and parasympathic stimulation. Anat. Rec., 71, 319-335.

Véghelyi, P. F., and Kemény, T. T. (1962). Protein metabolism and pancreatic function. In Ciba Foundation Symposium on the Exocrine Pancreas, edited by A. V. S. de Reuck and M. P. Cameron, pp. 329-352. Churchill, London. 